\title{
Productivity and Sustainability of Green Gram as Influenced by Improved Technology of CFLD under Hyper Arid Partially Irrigated Zone of Rajasthan
}

\author{
M. L. Reager*, Upendra Kumar, B. S. Mitharwal and Deepak Chaturvedi \\ Krishi Vigyan Kendra, Swami Keshwanand Rajasthan Agricultural University, \\ Bikaner-334006, Rajasthan, India \\ *Corresponding author
}

\section{A B S T R A C T}

K e y w o r d s
Green gram,
Sustainability yield
index,
Sustainability value
index, Improved
technology

Keywords

Green gram,

Sustainability yield

index, Improved

echnology

\section{Accepted:}

Available Online

10 May 2020
The field experiments on green gram was carried out during four consecutive years 2016 to 2019 at farmer's field of Bikaner districts under cluster frontline demonstrations conducted by Krishi Vigyan Kendra, Bikaner to evaluate improved technology for enhancing the productivity and economics of green gram crop. Two treatments were evaluated at 25 farmers and comprised of improved technology (i.e. high yielding varieties, seed treatment, timely sowing, recommended fertilizer management, plant protection measures and irrigation management compared with farmer's practice. Results revealed that improved technology demonstration gave higher and sustainable yield of green gram over the years compared to farmers practice. The mean yield recorded $\left(811 \mathrm{~kg} \mathrm{ha}^{-1}\right)$ which was 24.39 percent higher as compared to farmers practice $(652 \mathrm{~kg} / \mathrm{ha})$. Sustainability of green gram yield reflects the higher sustainability yield index (0.662) and sustainability value index $(0.517)$ Improved technology posses higher water expense efficiency $\left(54.0 \mathrm{~kg} \mathrm{ha}-\mathrm{cm}^{-1}\right)$ and incremental benefit cost ratio (7.4) over farmers practice.

\section{Introduction}

India is the major pulses producer country, accounting 25 per cent of global pulses production under 35 per cent of the total area. In a vegetarian country like India, where protein demand is fulfilled through pulses are the cheapest and concentrated source of dietary amino acids, so it is also considered as
"A poor man's meat". Pulses occupy a unique position in the world of agriculture by virtue of its high protein content, which is almost double than that of cereals.

In addition to protein, pulses also contain good quality lysine, tryptophan, ascorbic acid and riboflavin. Pulses are suitable for people with diabetes, also for coronary heart disease 
and anemia, as they regulate the cholesterol. The presence of bioactive compounds i.e. phytochemicals and antioxidants, build up an anti-cancer properties in pulses. In our country, green gram is an important pulse short duration and photo insensitive crop mostly grown in kharif under rainfed and irrigated conditions, rotationally with cereals. It is one of the most suitability for human health, as contains 25 per cent of high digestible proteins and consumed both as whole grain as well as split dal. Green gram is also good for environment as the wonderful gift of nature have an ability to fix the atmospheric nitrogen $\left(\mathrm{N}_{2}\right)$, thereby helps in $\mathrm{N}$ cycling within the ecosystem. Besides $\mathrm{N}_{2}$ fixation, incorporation of crop residue increases the microbial activity, restores soil properties in soil and carbon sequestration, and thus provides sustainability in crop production system. As a soil building crop green gram fixes atmospheric nitrogen through symbiotic action and also be used as green manure crop adding $34 \mathrm{~kg} \mathrm{~N} \mathrm{ha}^{-1}$.

The production and life support systems in the hot regions are constrained by low and erratic precipitation (100-420 $\mathrm{mm} /$ year), extreme temperatures $\left(45^{\circ} \mathrm{C}\right.$ in peak of summer), high evapotranspiration (1500-2000 $\mathrm{mm} /$ year $)$, poor soil fertility and physical conditions. This has resulted in over-exploitation of the resources causing rapid widespread land degradation and decline in productivity. Besides, harsh climatic conditions, soils of the region are coarse textured, poor in organic matter, available $\mathrm{N}$ and P (Singh et al., 2018) and have low water holding capacity.

Furthermore, traditional methods of cultivation like use of non-descript seed with little or no use of external inputs, over use irrigation for growing the crops with broadcast methods further deteriorates the situation. Moreover, diverse problems with socio-economic and infrastructural backwardness do not allow the farmers to additional invest on the use of improved production technologies. This may be due to partial adoption of recommended package of practices by the green gram growers. Technology gap is a major problem in increasing green gram production and sustainability. So far, not much systematic effort was made to study the technological gap existing in various components of green gram cultivation.

Indian government imports large quantity of pulses to fulfill domestic requirement of pulses. In this regard, to sustain this production and consumption system, the Department of Agriculture, Cooperation and Farmers Welfare had sanctioned the project "Cluster Frontline Demonstrations on kharif pulses from 2016" to ICAR-ATARI, Jodhpur through National Food Security Mission. The basic strategy of the Mission is to promote and extend improved crop management practices and innovative technology, i.e., quality seed, micro-nutrients, soil amendments, weed management, integrated pest management, irrigation scheduling along with capacity building of farmers.

This project was implemented by Krishi Vigyan Kendra, Bikaner- I of Zone-II, as grass root level organization meant for application of technology through assessment, refinement and demonstration of proven technologies under different micro farming situation in a district. Keeping this in view, cluster front line demonstrations were organized in participatory mode to enhance the productivity; economic returns and sustainability with the objective analyze the yield gaps and impact of technology on sustainability in green gram cultivation on the newly recommended package of practice. 


\section{Materials and Methods}

The field experiments of 0.40 ha each were conducted at 25 farmers fields in four adopted villages of Bikaner district of Rajasthan under cluster frontline demonstration (CFLD) of National Food Security Mission (NFSM) during four consecutive kharif seasons of 2016 to 2019 , to evaluate economic feasibility and sustainability of improved technology in green gram. Before conducting CFLDs, a list of farmers was prepared from group meeting and specific skill training was given to the selected farmers regarding package of practices. The difference between demonstration package and existing farmers practices are given in Table 1. The improved technology demonstration included high yielding varieties, seed treatment, timely sowing, fertilizer management, plant protection measures and irrigation management.

The sowing was done in the month of July. The spacing was 30x10 $\mathrm{cm}$ apart and the seed rate of green gram was $15 \mathrm{~kg} \mathrm{ha}{ }^{-1}$. The fertilizers were given as per soil testing value; however, the average recommended dose of fertilizer applied in the demo plots was $20 \mathrm{~kg}$ $\mathrm{N}, 40 \mathrm{~kg} \mathrm{P}_{2} \mathrm{O}_{5}, 40 \mathrm{~kg} \mathrm{~K} \mathrm{~K}_{2} \mathrm{O}$ and $25 \mathrm{~kg} \mathrm{~S}$ per hectare. The NPK \& S fertilizers were applied through Urea, SSP, MOP \& elemental S respectively, at the time of sowing. The two sprays of $\mathrm{FeSo}_{4}$ and $\mathrm{ZnSo}_{4}$ were done due to deficiency occurring during growth period of crop. Soils under study were loamy sand in texture with a $\mathrm{pH}$ range of 8.3 to 8.7. The soils poor in available nitrogen, medium in phosphorous and potassium varied between 250-260, 15-19 and 227-230 kg harespectively. However, the soils were deficient in micro nutrients particularly, zinc and ferrous. In demonstration plots, critical inputs in the form of quality seeds of improved varieties, micronutrient fertilization, herbicide, timely sowing, and need based of pesticides as well as, irrigation time were emphasized by the KVK and comparison has been made with the existing practices (Table 1). The necessary step for the selection of site and farmers and lay out of demonstration were followed as suggested by Chaudhary (1999).

The traditional practices were maintained in case of local check. The data output were collected from both CFLD plots as well as control plot and finally the extension gap, technology gap, technology index along with the incremental benefit-cost ratio were calculated as suggested by Raj et al., (2013). Data were recorded at harvest from each demonstration blocks and farmer's practice blocks. These recorded data were computed and analyzed for different parameters using following formulae suggested by Prasad et al., (1993).

Extension Gap=Demonstration yield (Di) Farmers practice yield (Fi)

Technology $\mathrm{Gap}=$ Potential yield $(\mathrm{Pi})$ Demonstration yield (Di)

Technology Index $=(\mathrm{Pi}-\mathrm{Di}) / \mathrm{Pi}$ x 100

Data were further analyzed for standard deviation and coefficient of variation as per standard procedure given by Panse and Sukhatme (1961). Sustainability indices (sustainability yield index and sustainability value index) were work out using formulae given by Singh et al., 1990.

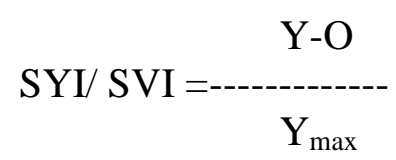

Where, $\mathrm{Y}=$ Estimated average yield/ net return of practices over the year

$\mathrm{O}=$ Standard deviation

$\mathrm{Y}_{\max }=$ Maximum yield/maximum net return . 


\section{Results and Discussion}

\section{Seed yield}

Seed yield of green gram varied from 587$1070 \mathrm{~kg} \mathrm{ha}^{-1}$ in improved technology and 400$860 \mathrm{~kg} / \mathrm{ha}$ in farmers practice (Table 2). Four year mean seed yield of demonstrations of green gram was $811 \mathrm{~kg} \mathrm{ha}^{-1}$ which was 24.38 per cent higher over four years mean yield $(652 \mathrm{~kg} / \mathrm{ha})$. Year wise per cent increase in seed yield of green gram demonstrations over farmer's practices ranged to the tune of 23.03 to 32.25. The higher seed yield under demonstrations could be attributed to adoption of improved technology and ultimately enhanced green gram productivity. Year wise variation in seed yield was observed might be due to variation in environmental conditions prevailed during that particular year. Similar finding was reported by Bhargav et al., (2017) stated that improved package of practices has shown positive effect on yield potentials of different crops. Test blocks green gram higher mean water expanse efficiency $\left(54.0 \mathrm{~kg} \mathrm{ha-} \mathrm{cm}^{-1}\right)$ as compared to farmers practice. This might be due to effective depth of irrigation water applied and obtained higher yields. The results corroborate the finding of Singh et al., (2013) and Bhan et al., (2014).

\section{Adoption gap}

Data (Table 3) revealed that adoption gap is a key factor for enhancing the productivity of green gram. Gap analysis was done by evaluating the extension gap, technology gap and technological index to measure the magnitude of adoption technology. Extension gap is a parameter to know the yield difference between the demonstrated technology and farmers practice and observed data further indicated that extension gap varied from 152 to $169 \mathrm{~kg} \mathrm{ha}^{-1}$ with an average of $1.59 \mathrm{~kg} \mathrm{ha}^{-1}$. This indicated a wide gap between the demonstrated improved technology and the farmers practice.

Technology gap is a measure of difference between potential yield and yield obtained under improved technology demonstration. It has a great significance than other parameters as it indicates the constraints in implementation of technology and drawbacks in our package of practices. This also reflects the poor extension activities, which resulted in lesser adoption of improved water management technology and package of practices by the farmers.

This gap can be bridge by strengthening the extension activities and further on farm research to improve the package of practices. Technology index is dependent on technology gap and is a function expressed in per cent age. Technology index of four years of study varied from 17.5 to 42.3 per cent with an average of 32.1 per cent. The very low technology index (17.5) during the year 2016 could be due to adoption of improved technology, favorable climatic conditions, free from insect pest and disease incidence. High technology index shows a poor adoption of package of practices and demonstrated technology by the farmers. The findings in front line demonstrations in accord with Patil et al., (2015) and Meena et al., (2018).

\section{Economics}

Seed yield, cost of variable inputs and sale price of produce determine the economic returns and these vary from year to year as the cost of input, labour and sale price of produce changes from time to time (Table 4).

The year wise additional returns from improved technology demonstrations over farmer's practice varied from Rs $7604 \mathrm{ha}^{-1}$ to Rs $9798 \mathrm{ha}^{-1}$ and average additional return of Rs $8782 \mathrm{ha}^{-1}$. The mean additional cost of input of all the demonstrations for four years was Rs. 1200/ha. 
Table.1 Comparison between demonstration packing and existing practices under green gram crop

\begin{tabular}{|c|c|c|c|}
\hline \multirow[t]{2}{*}{ S. No. } & \multirow[t]{2}{*}{ Particulars } & \multicolumn{2}{|c|}{ Green gram Crop } \\
\hline & & Demonstration & Farmers Practice \\
\hline 1. & Farming situation & Irrigated & Irrigated \\
\hline 2. & Variety & SML-668 and MH-421 & K-851 or Local seed \\
\hline 3. & Time of sowing & First or second week of July & First or second week of July \\
\hline 4. & Method of sowing & $\begin{array}{l}\text { The line sowing of seed with row spacing of } 30 \mathrm{~cm} \text {. } \\
\text { was done after application of basal fertilizer dose }\end{array}$ & $\begin{array}{l}\text { Some farmers adopted line sowing with } 30 \\
\text { cm. row spacing. However mostly farmers use } \\
\text { broadcasting method of sowing. } \\
\text { The fertilizers mixing with seed is a common } \\
\text { practice in sowing. }\end{array}$ \\
\hline 5. & Seed treatment & Carbendazim@2.0 $\mathrm{g} \mathrm{kg}^{-1}$ seed & No seed treatment \\
\hline 6. & Seed rate & $15 \mathrm{~kg} \mathrm{ha}^{-1}$ & $20 \mathrm{~kg} \mathrm{ha}^{-1}$ \\
\hline 7. & Fertilizer dose & NPKS Zn $(20: 40: 40: 25: 25)$ & NPKS Zn (56:24:00:25:00) \\
\hline 8. & Micronutrient & $\begin{array}{c}\text { Two sprays of } 0.5 \% \mathrm{FeSo}_{4} \text { with citric acid and } \mathrm{ZnSo}_{4} \\
\text { with lime were done due to deficiency occurring } \\
\text { during growth period of crop. }\end{array}$ & $\mathrm{ZnSo}_{4}$ applied with irrigation water \\
\hline 9. & Irrigation & First at $30 \mathrm{DAS}$ and then irrigated 3 times & $\begin{array}{l}\text { First at } 10-15 \text { DAS and then applied continue } \\
\text { up to } 4-5 \text { irrigations }\end{array}$ \\
\hline 10. & Weed management & $\begin{array}{l}\text { Application of pre-emergence herbicide pendimethalin } \\
\text { @ } 1.00 \mathrm{~kg} \mathrm{ha}^{-1} . \text { If the weeds emerge after planting, } \\
\text { Imazethapyr @ } 37.5 \mathrm{~g} \text { a.i. ha } \mathrm{h}^{-1} \text { as post-emergence } \\
\text { sprayed at } 30 \text { days after sowing. }\end{array}$ & $\begin{array}{l}\text { Application pendimethalin @ } 1.00 \mathrm{~kg} \mathrm{ha}^{-1} \text { as } \\
\text { pre emergence but applied with irrigation } \\
\text { water. }\end{array}$ \\
\hline 11. & Plant protection & $\begin{array}{c}\text { Approaches of Integrated pest and disease } \\
\text { management for the management of pest and diseases. } \\
\text { Spray of COC @ } 30 \mathrm{~g}+2 \mathrm{~g} \text { streptocycline per } 10 \text { litre } \\
\text { of water against bacterial blight. } \\
\text { Spray of Quinalphos } 25 \text { E.C. @ } 1.2 \text { litre against pod } \\
\text { borer and monocrotophos } 36 \text { SL } 1.0 \text { litre ha }{ }^{-1} \text { against } \\
\text { white fly attack. }\end{array}$ & Injudicious use of pesticides and fungicides. \\
\hline
\end{tabular}


Table.2 Effect of improved technology demonstrations on seed yield and net return of green gram



IT=Improved technology $\mathrm{FP}=$ Farmers practice $\mathrm{S} . \mathrm{D}=\mathrm{Standard}$ deviation 
Table.3 Effect of improved technology demonstrations on seed yield, water expense efficiency and gap indices of green gram

\begin{tabular}{|c|c|c|c|c|c|c|c|c|c|}
\hline \multirow[t]{2}{*}{ Year } & \multicolumn{2}{|c|}{ Yield $\left(\mathrm{kg} \mathrm{ha}^{-1}\right)$} & \multirow{2}{*}{$\begin{array}{c}\text { \% increase } \\
\text { over FP }\end{array}$} & \multicolumn{2}{|c|}{ WEE $\left(\mathrm{kg} \mathrm{ha}^{\left.-\mathrm{cm}^{-1}\right)}\right.$} & \multirow{2}{*}{$\begin{array}{l}\text { Potential yield } \\
\left(\mathrm{kg} \mathrm{ha}^{-1}\right)\end{array}$} & \multirow{2}{*}{$\begin{array}{l}\text { Extension gap } \\
\quad\left(\mathrm{kg} \mathrm{ha}^{-1}\right)\end{array}$} & \multirow{2}{*}{$\begin{array}{l}\text { Technology gap } \\
\quad\left(\mathrm{kg} \mathrm{ha}^{-1}\right)\end{array}$} & \multirow{2}{*}{$\begin{array}{c}\text { Technology } \\
\text { index }(\%)\end{array}$} \\
\hline & IT & $\mathbf{F P}$ & & IT & FP & & & & \\
\hline 2016 & 907 & 751 & 20.8 & 60.5 & 30.0 & 1100 & 156 & 193 & $\mathbf{1 7 . 5}$ \\
\hline 2017 & 812 & 660 & 23.1 & 54.1 & 26.4 & 1200 & 152 & 388 & 32.4 \\
\hline 2018 & 693 & 524 & 32.2 & 46.2 & 21.0 & 1200 & 169 & 507 & 42.3 \\
\hline 2019 & 831 & 673 & 23.5 & 55.4 & 26.9 & 1300 & 158 & 469 & 36.1 \\
\hline Mean & 811 & 652 & 24.9 & 54.0 & 26.1 & 1200 & 159 & 389 & 32.1 \\
\hline
\end{tabular}

IT=Improved technology $\mathrm{FP}=$ Farmers practice

Table.4 Effect of improved technology demonstrations on economics of green gram

\begin{tabular}{|c|c|c|c|c|c|c|c|c|c|}
\hline \multirow[t]{2}{*}{ Year } & \multicolumn{2}{|c|}{ Cost of inputs $\left(\mathrm{Rs} \mathrm{ha}^{-1}\right)$} & \multirow{2}{*}{$\begin{array}{l}\text { Additional cost in } \\
\text { IT }\left(\mathrm{Rs} \mathrm{ha}^{-1}\right)\end{array}$} & \multirow{2}{*}{$\begin{array}{l}\text { Sale price } \\
\left(\operatorname{Rs~q}^{-1}\right)\end{array}$} & \multicolumn{2}{|c|}{ Total return ( $\left.\mathrm{Rs} \mathrm{ha}^{-1}\right)$} & \multirow{2}{*}{$\begin{array}{l}\text { Additional return } \\
\text { in IT }\left(\mathrm{Rs} \mathrm{ha}^{-1}\right)\end{array}$} & \multirow{2}{*}{$\begin{array}{l}\text { Effective gain } \\
\quad\left(\mathrm{Rs} \mathrm{ha}^{-1}\right)\end{array}$} & \multirow[t]{2}{*}{ IBCR } \\
\hline & IT & FP & & & IT & FP & & & \\
\hline 2016 & 15000 & 14000 & 1000 & 5400 & 48989 & 40549 & 8440 & 7440 & 8.4 \\
\hline 2017 & 15500 & 14500 & 1000 & 5000 & 40584 & 32980 & 7604 & 6604 & 7.6 \\
\hline 2018 & 15800 & 14500 & 1300 & 5500 & 38096 & 28809 & 9287 & 7987 & 7.1 \\
\hline 2019 & 16500 & 15000 & 1500 & 6200 & 51512 & 41714 & 9798 & 8298 & 6.5 \\
\hline Mean & 15700 & 14500 & 1200 & 5525 & 44795 & 36013 & 8782 & 7582 & 7.4 \\
\hline
\end{tabular}

IT=Improved technology FP=Farmers practice 
The higher sale price of produce in spite of low production and lower additional cost of input during 2019 gave highest additional return (Rs $8298 \mathrm{ha}^{-1}$ ) under improved technology demonstrations over farmer's practice.

The mean incremental benefit cost ratio (IBCR) fetched was 7.4 and it showed the positive impact of improved technology. The highest IBCR (8.4) was observed in 2016 and least in 2019 (6.5). This is due to comparatively higher grain yield, less cost of input and a good sale price of produce (Trivedi et al., 2019 and Singh et al., 2012).

\section{Sustainability}

A perusal of data (Table 2) depicted that higher standard deviation (SD) and coefficient of variation $(\mathrm{CV})$ in yield were observed under farmer's practices over improved technology demonstrations for all the four years. This may be due to more variation in the yield of farmer's practice from farmer to farmer and least variation in improved technology demonstrations. However, the maximum values of sustainability yield index (SYI) and sustainability value index (SVI) were found under improved technology than farmer's practices. The mean SYI and SVI over these four years under improved technology varied from 0.768 to 0.821 and 0.655 to 0.720 whereas, corresponding values under farmers practice were 0.695 to 0.774 and 0.522 to 0.668 respectively. Pooled data further revealed that SYI and SVI increased to the tune of 9.99 and 19.12 per cent over farmers. This shows that the improved technology is more sustainable as compared to farmer's practice. Similar results have been reported by Narolia et al., (2013).

\section{References}

Bhan, Chander, Chawala, Seema, Sidhu, B. S. and Bhati, D. S. (2014). Impact of front line demonstration on production technology of Moong (Vigna radiata) in Sriganganagar district of Rajasthan. $J$. Progress. Agric., 5 (2): 59-61.

Bhargav, K. S., Gupta, N., Pandey, A. Patel, N. and Dixit, A. K. (2017). Impact of front line demonstration on production and productivity of summer moong, Agriculture Update 12 (6): 1656-1659.

Choudhary, B.N. (1999). Krishi Vigyan Kendra- guide for KVK managers. Publication, Division of Agril. Extn., ICAR, pp 73-78.

Meena, O.P., Sharma, K. C., Meena, R.H. and Mitharwal, B.S. (2012). Technology transfer through FLDs on mung bean in semi-arid region of Rajasthan. Raj. J. Extn. Edu. 20 : 182-186.

Narolia, R.S., Singh, P Mathur, I.N Ram, B. and Raigar, P.R. (2013). Impact of improved water management technology on productivity and sustainability of mustard under chambal command. Indian Journal of Natural Products and Recourses, 4(3):317-320.

Panse VG and Sukhatme VP.1985. Statistical methods for agricultural workers. Indian Council of Agricultural Research, New Delhi.

Patil, L. M., Modi, D. J., Vasava, H. M. and Gomkale, S. R. (2015). Evaluation of front line demonstration programme on green gram variety meha (IPM-99-125) in Bharuch district of Gujarat. Journal of Agriculture and Veterinary Science, 8(9): 2319-2380

Prasad Y, Rao E, Manchar $M$ and Vijaybhinanda R. 1993. Analysis of onfarm trials and level of technology on oilseeds and pulse crops in Northern Telangana Zone of Andra Pradesh. Indian Journal of Agricultural Economics 48: 351-56.

Raj, A.D., Yadav, V. and Rathod, J. H. (2013). Impact of Front Line Demonstrations (FLD) on the Yield of 
Pulses. International Journal of Scientific and Research Publications, 3(9):1-4.

Singh Dheeraj, Chaudhary M K, Meena M L and Roy M M. 2013. Seed village programme: An innovative approach for small farmers. Agricultural Information Worldwide 6: 143-6.

Singh RP, Das SK, Bhaskar Rao UM and Narayana Reddy M. 1990. Towards Sustainable Dry land Agricultural Practices. Bulletin published by CRIDA, Hyderabad, India. pp. 1-106.

Singh, J., Dhillon, B.S., Astha and Singh, P. (2012). Front line demonstration-An effective tool for increasing the productivity of summer Moong in Amritsar district of Punjab. An Asian Journal of Soil Science, 7(2):315-318.
Singh, R., Dogra, A., Sarkar, A., Saxena, A. and Singh, B. (2018). Technology gap, constraint analysis and improved production technologies for yield enhancement of barley (Hordeum vulgare) and chickpea (Cicer arietinum) under arid conditions of Rajasthan. Indian Journal of Agricultural Sciences 88 (2): 93-100.

Trivedi, H.K. Jain, V.K. Tomar, S.S. Gupta, B.S. and Panika A.K. (2019). Enhancing the Productivity of Green gram (moong) through Cluster Front Line Demonstration in the Ashoknagar District of Madhya Pradesh. TECHNOFAME- A Journal of Multidisciplinary Advance Research, 8 (2):63-66.

\section{How to cite this article:}

Reager, M. L., Upendra Kumar, B. S. Mitharwal and Deepak Chaturvedi. 2020. Productivity and Sustainability of Green Gram as Influenced by Improved Technology of CFLD under Hyper Arid Partially Irrigated Zone of Rajasthan. Int.J.Curr.Microbiol.App.Sci. 9(05): 17781786. doi: https://doi.org/10.20546/ijcmas.2020.905.201 